\title{
Structural and Dynamic Properties of Gallium Alkoxides
}

\author{
Kristian L. Mears, ${ }^{\dagger}$ Leanne G. Bloor, ${ }^{\dagger}$ David Pugh, ${ }^{\ddagger}$ Abil E. Aliev, ${ }^{\dagger}$ Caroline E. Knapp, ${ }^{\dagger}$ (1) \\ and Claire J. Carmalt ${ }^{*} \dagger$ \\ ${ }^{\dagger}$ Materials Chemistry Centre, Department of Chemistry, University College London, 20 Gordon Street, London WC1H 0AJ, United \\ Kingdom \\ ${ }^{\ddagger}$ Molecular Sciences Research Hub, Imperial College London, 80 Wood Lane, London, W12 0BZ, United Kingdom
}

\section{Supporting Information}

\begin{abstract}
A comparison of chlorido-gallium functionalized alkoxides as precursors for aerosol-assisted chemical vapor deposition (AACVD) was carried out. Variabletemperature (VT)-NMR studies were used to probe the fluxional behavior of these alkoxides in solution, and hence their utility as precursors. The synthesis involved the initial isolation of the dimer $\left[\mathrm{GaCl}\left(\mathrm{NMe}_{2}\right)_{2}\right]_{2}$ via a salt metathesis route from $\mathrm{GaCl}_{3}$ and 2 equiv of $\mathrm{LiNMe}_{2}$. This dimer was then reacted with 4 equiv of $\mathrm{HOCH}_{2} \mathrm{CH}_{2} \mathrm{CH}_{2} \mathrm{NEt}_{2}$, resulting in the formation of $\mathrm{Ga}\left[\mu-\left(\mathrm{OCH}_{2} \mathrm{CH}_{2} \mathrm{CH}_{2} \mathrm{NEt}_{2}\right)_{2} \mathrm{GaCl}_{2}\right]_{3}(\mathbf{1})$. Mass spectrometry and VT-NMR confirmed the oligomeric structure of 1 . Tuning of the ligand properties, namely, the chain length and substituents on $\mathrm{N}$, resulted in formation of
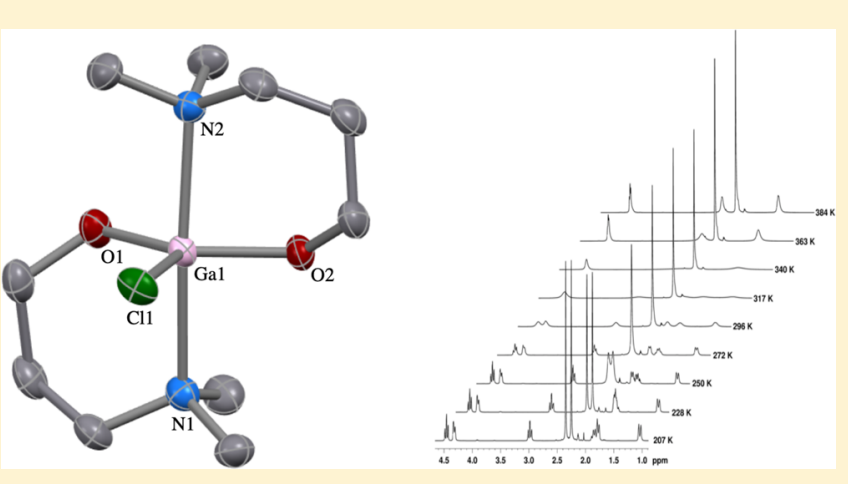
the monomers $\left[\mathrm{GaCl}(\mathrm{OR})_{2}\right]\left(\mathrm{R}=\mathrm{CH}_{2} \mathrm{CH}_{2} \mathrm{NEt}_{2},(2) ; \mathrm{CH}_{2} \mathrm{CH}_{2} \mathrm{CH}_{2} \mathrm{NMe}_{2},(3)\right)$. VT-NMR studies, supported by density functional theory calculations, confirmed that the ligands in both 2 and 3 possess a hemilabile coordination to the gallium center, owing to either a shorter carbon backbone (2) or less steric hindrance (3). Both 2 and 3 were selected for use as precursors for AACVD: deposition at $450{ }^{\circ} \mathrm{C}$ gave thin films of amorphous $\mathrm{Ga}_{2} \mathrm{O}_{3}$, which were subsequently annealed at 1000 ${ }^{\circ} \mathrm{C}$ to afford crystalline $\mathrm{Ga}_{2} \mathrm{O}_{3}$ material. The films were fully characterized by $\mathrm{X}$-ray diffraction, $\mathrm{X}$-ray photoelectron spectroscopy, scanning electron microscopy, UV-visible spectroscopy, and energy dispersive X-ray analysis.
\end{abstract}

\section{INTRODUCTION}

In recent years, the research surrounding metal oxide thin films, particularly those containing group 13 elements, has expanded greatly due to these materials having properties crucial to the function and performance of a wide variety of electronic, optical, and chemically active devices, including photovoltaic cells, ${ }^{1}$ gas sensors, ${ }^{2}$ transparent conducting oxides (TCOs), ${ }^{3}$ as well as screen displays. ${ }^{4}$ Gallium oxide $\left(\mathrm{Ga}_{2} \mathrm{O}_{3}\right)$ is a material that exists in various forms, with two prevailing due to their increased thermodynamic stability, $\alpha-\mathrm{Ga}_{2} \mathrm{O}_{3}$ and $\beta-\mathrm{Ga}_{2} \mathrm{O}_{3}$ being metastable and stable, respectively. The $\beta-\mathrm{Ga}_{2} \mathrm{O}_{3}$ form has a wide band gap of $4.7 \mathrm{eV}^{5}$ and performs well as an $n$-type semiconductor in the temperature range of $450-550{ }^{\circ} \mathrm{C}$. Recent work has shown the use of gallium oxide thin films as solar-blind photodetectors, ${ }^{7}$ in which high selectivity for ultraviolet (UV) light in the presence of visible light affords one of the highest responsivity reported $\left(1.8 \times 10^{5} \mathrm{~A} \mathrm{~W}^{-1}\right)$ when compared to other photodetectors such as $\mathrm{AlGaN}, \mathrm{GaN}$, and $\mathrm{MgZnO}$. Other recent work highlighting the utility of $\mathrm{Ga}_{2} \mathrm{O}_{3}$ includes improving the sensitivity of the gas sensing ability of $\mathrm{ZnO}$ toward $\mathrm{NO}_{2}$ when doped with $\mathrm{Ga}_{2} \mathrm{O}_{3}{ }^{8}$. Many routes toward gallium oxide thin films have been outlined in the literature using a variety of techniques, such as aerosol-assisted chemical vapor deposition (AACVD), ${ }^{9-12}$ spin coating, ${ }^{13}$ and pulsed layer deposition, ${ }^{14}$ to name but a few. ${ }^{15}$ Homoleptic oxygen containing gallium complexes have been investigated as precursors to $\mathrm{Ga}_{2} \mathrm{O}_{3}$, including $\beta$-diketonates, ${ }^{11}[\mathrm{Ga}$ $\left.(\mathrm{acac})_{3}\right]^{16,17}$ and $\left[\mathrm{Ga}(\mathrm{dbm})_{3}\right]^{18}$ (acac $=$ acetylacetonate, and $\mathrm{dbm}=$ dibenzoylmethanoate $)$, where tris- $\beta$-diketonate gallium(III) complexes have been isolated. Others include $\beta$ ketoiminates, ${ }^{13,19-21}$ of the general formula [4-[2-(R)imino]2-pentanone] gallium(III), ( $\mathrm{R}=\mathrm{CH}_{2} \mathrm{CH}_{2} \mathrm{CH}_{2} \mathrm{OCH}_{2} \mathrm{CH}_{3}$, $\mathrm{CH}\left(\mathrm{CH}_{3}\right)_{2}, \mathrm{CH}_{2} \mathrm{CH}_{2} \mathrm{OCH}_{3}, \mathrm{CH}_{2} \mathrm{CH}_{2} \mathrm{CH}_{2} \mathrm{OCH}_{3}$, and $\mathrm{CH}_{2} \mathrm{CH}_{2} \mathrm{OCH}_{2} \mathrm{CH}_{3}$ ), ${ }^{13,21}$ and further contributions (Figure 1) have recently detailed the synthesis of oxygen-rich gallium complexes with dimethylmalonate and cyclopropane-1,1dimethylester ligands for use in catalysis ${ }^{22}$ and di(tert-butyl)gallium species with $\beta$-diketonato ligands, which were further functionalized with molecular oxygen to form metal-stabilized peroxides. $^{23}$

Though these $\beta$-diketonato-gallium complexes were not used for the deposition of gallium oxide, the merit of these galliumoxygen systems is evidenced by their ability to stabilize highly reactive metal-carbon bonds which can be further functionalized to increase the stoichiometry of oxygen of the

Received: $\quad$ May 24, 2019 


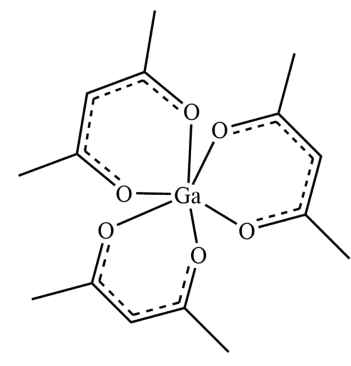

A

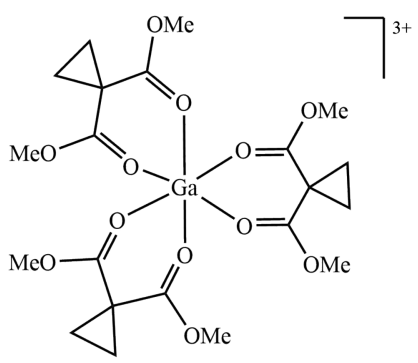

D<smiles>C1=C(c2ccccc2)C=C(c2ccccc2)C=C(c2ccccc2)OC2(OC=C(c3ccccc3)O2)OC(c2ccccc2)C=C(c2ccccc2)C=C1c1ccccc1</smiles>

B

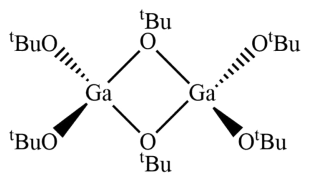

$\mathbf{E}$

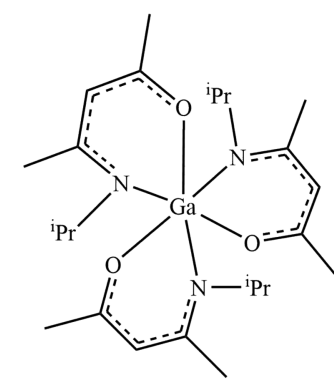

C

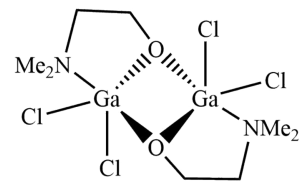

Figure 1. Examples of oxygen-rich gallium compounds previously reported. Gallium $\beta$-diketonates: $(\mathbf{A})\left[\mathrm{Ga}(\mathrm{acac})_{3}\right]^{16,17} \mathrm{and}(\mathbf{B})\left[\mathrm{Ga}(\mathrm{dbm})_{3}\right]^{18}$ Gallium $\beta$-ketoiminate: (C) $\left[\mathrm{Ga}(4 \text {-[2-(isopropyl)imino]-2-pentanone) })_{3}\right] .{ }^{13}$ Gallium dimethylester: (D) $\left[\mathrm{Ga} \text { (cyclopropane-1,1-dimethylester) }{ }_{3}\right]^{3+} \cdot{ }^{22}$ Gallium alkoxides: (E) $\left[\mathrm{Ga}\left(\mathrm{O}^{t} \mathrm{Bu}\right)_{3}\right]_{2}{ }^{24}$ and $(\mathbf{F})\left[\mathrm{GaCl}_{2}\left(\mathrm{OCH}_{2} \mathrm{CH}_{2} \mathrm{NMe}_{2}\right)\right]_{2}{ }^{25}$

compound. ${ }^{23} \beta$-Diketoiminate complexes form a conjugated sixmembered ring intramolecularly through the $\mathrm{O}$ and $\mathrm{N}$ donor atoms and the metal center, increasing the thermal stability of the complex and lowering the melting point. ${ }^{21}$ The $\mathrm{R}$ group bound to the imide $\mathrm{N}$ atom of the $\beta$-diketoiminates can be further functionalized depending on the requirements of the precursor and the material to be deposited. ${ }^{26}$

Gallium alkoxides have also shown potential as precursors to $\mathrm{Ga}_{2} \mathrm{O}_{3}$ thin films. ${ }^{25}$ When comparing alkoxides to $\beta$ diketoiminates, increased functionalization can also be obtained from alkoxide precursors, where donor-functionalized alcohols featuring an amine group allow the $\mathrm{N}$ atom to tether to the metal center, and the R groups associated with the amine, as well as the length of the alcohol's carbon backbone, can be varied to improve solubility and stability. ${ }^{27}$ A benefit associated with the use of functionalized alkoxides of gallium (specifically bis(alkoxides), which can be difficult to synthesize and are uncommon compared to their diorganoalkoxometallane analogues $)^{10}$ is that they are monomeric in nature, as the pendant donor atom's electronic contribution saturates the metal's coordination sphere, reducing the tendency for oligomerization to occur, making them excellent precursors for CVD. ${ }^{25,27,28}$

Previously, we have investigated the stepwise route to alkyl/ chloro-gallium donor-functionalized alkoxides from the reactions of gallium chloride with lithium dimethylamide ${ }^{27}$ and lithium hexamethyldisilazide, ${ }^{25}$ including an in-depth crystal structure analysis. Other works report of functionalization through ethers, ${ }^{29}$ and more recently, even thioethers to deposit oxysulfide thin films. ${ }^{30,31}$ Gallium/copper mixed-metal thiolate compounds, $^{32}$ used for potential gallium copper sulfide materials, were shown to have simple room-temperature NMR spectra; however, low-temperature NMR studies revealed the complex dissociative mechanisms that these precursors undergo in solution. This information can be used to understand thermolytic pathways during deposition to the target material.
Variable-temperature (VT)-NMR studies, to the best of our knowledge, have not been used to understand the fluxional behavior of gallium bis(alkoxides) in solution (though recently gallium complexes from methylidenemalonates have been probed with VT-NMR to understand the differences in stereochemistry and hence the reactivity of catalytically active gallium species) $)^{33}$ or, furthermore, how these mechanisms can be used as an aid in the understanding of precursor thermolysis. In this work, we extend the study through the synthesis of chloro-gallium bis (alkoxides ): Ga $[\mu-$ $\left.\left(\mathrm{OCH}_{2} \mathrm{CH}_{2} \mathrm{CH}_{2} \mathrm{NEt}_{2}\right)_{2} \mathrm{GaCl}_{2}\right]_{3}$ (1), and monomers of the form $\left[\mathrm{GaCl}(\mathrm{OR})_{2}\right]\left(\mathrm{R}=\mathrm{CH}_{2} \mathrm{CH}_{2} \mathrm{NEt}_{2}\right.$ (2), $\mathrm{CH}_{2} \mathrm{CH}_{2} \mathrm{CH}_{2}$ $\mathrm{NMe}_{2}(3)$ ). A study in solution via VT-NMR, supported by density functional theory (DFT) calculations, has facilitated the comparison of these compounds' effectiveness as precursors toward $\mathrm{Ga}_{2} \mathrm{O}_{3}$ thin films via AACVD.

\section{EXPERIMENTAL SECTION}

General Procedures. All syntheses were performed under a dry, oxygen-free argon atmosphere using standard Schlenk techniques or in an MBraun Unilab glovebox. All solvents used were stored in alumina columns and dried with anhydrous engineering equipment, such that the water concentration was 5-10 ppm. The gallium amide $\left[\mathrm{GaCl}\left(\mathrm{NMe}_{2}\right)_{2}\right]_{2}$ was prepared according to standard literature procedures. ${ }^{27}$ All other reagents were procured commercially from Aldrich, and the alcohols were degassed by three freeze-pump-thaw cycles and stored over $4 \AA$ molecular sieves. ${ }^{1} \mathrm{H}$ and ${ }^{13} \mathrm{C}$ NMR spectra were obtained on Bruker NMR spectrometers Avance III 400, Avance 500, and Avance Neo 700. Spectra were recorded using $\mathrm{CD}_{2} \mathrm{Cl}_{2}$, toluene- $d_{8}$, or $\mathrm{C}_{6} \mathrm{D}_{6}$ which were dried and degassed over molecular sieves prior to use. ${ }^{1} \mathrm{H}$ and ${ }^{13} \mathrm{C}\left\{{ }^{1} \mathrm{H}\right\}$ chemical shifts relative to TMS were calibrated using the residual solvent peak. High- and lowtemperature NMR calibrations were carried out using standard samples of $80 \%$ 1,2-ethanediol in DMSO- $d_{6}$ and $4 \% \mathrm{CH}_{3} \mathrm{OH}$ in $\mathrm{CD}_{3} \mathrm{OD}$, respectively. Data acquisition and processing were performed using standard Bruker TopSpin software. The mass spectra were obtained using a Micromass 70-SE spectrometer using chemical ionization (CI) 
Scheme 1. Synthesis of Donor-Functionalized Gallium Compounds 1-3

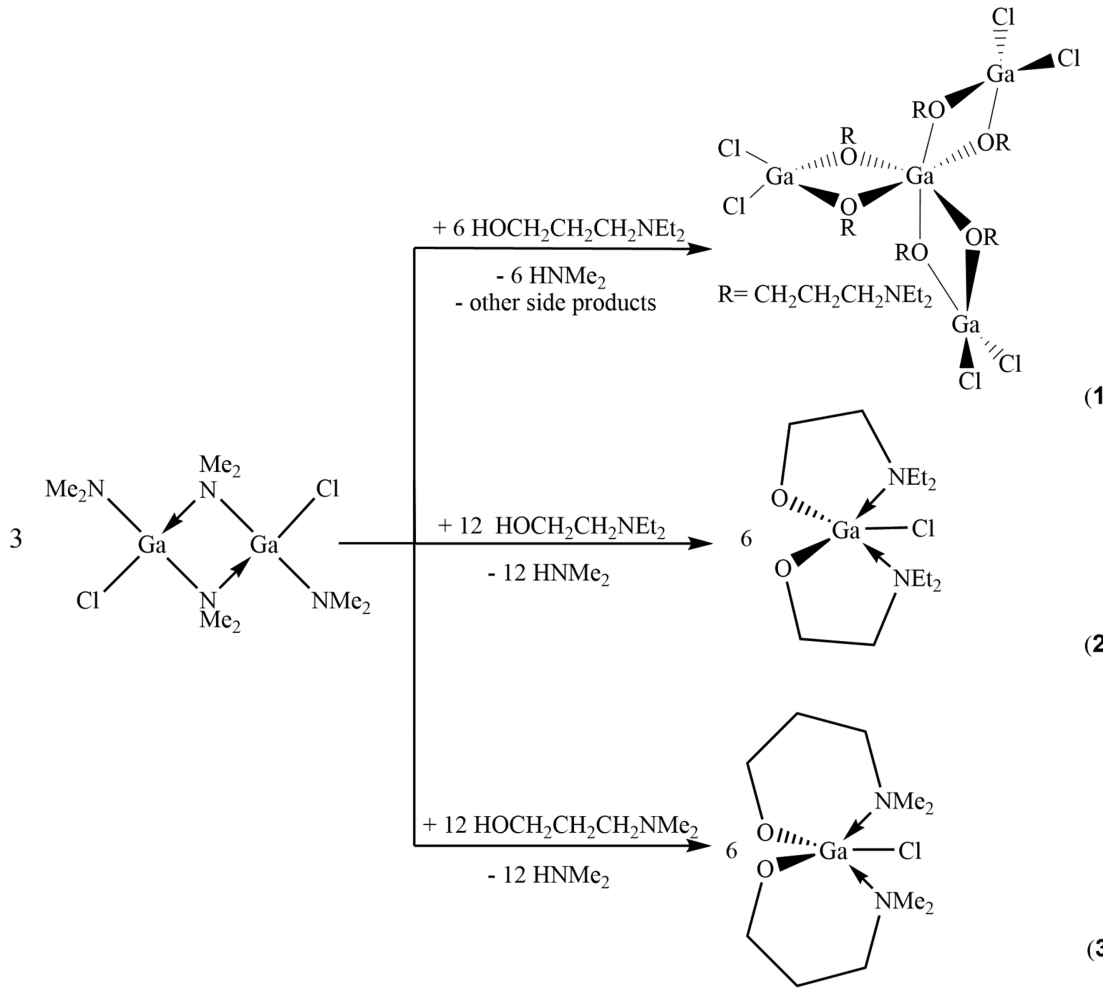

(1)

(3) with methane reagent gas, or using an LCT Premier QTOF spectrometer using electrospray ionization (ESI). Single crystals of 2 and 3 were analyzed on a Bruker SMART APEX diffractometer using graphite monochromated Mo K $\alpha$ radiation $(0.71073 \AA$ ) at $150.15 \mathrm{~K}$. Using Olex2, ${ }^{34}$ we solved the structure with the olex2.solve ${ }^{35}$ structure solution program using Charge Flipping and refined with the ShelXL ${ }^{36}$ refinement package using Least Squares minimization. Crystallographic information is available from the CSD, CCDC numbers: CCDC1917612 (2) and CCDC1917613 (3).

AACVD. Depositions were carried out under dinitrogen (99.99\% from $B O C)$. The synthesized precursors were placed into an inert AACVD glass bubbler and dissolved in an appropriate dry solvent. Two glass substrates were placed into a horizontal bed cold-wall reactor chamber, one resting on top of the graphite heating block, the second resting $0.5 \mathrm{~cm}$ above, ensuring a laminar flow of gas. The glass substrates were cleaned prior to deposition with isopropyl alcohol, water, and acetone and allowed to dry in air before the deposition took place. The temperature of the graphite block was controlled with a thermocouple composed of platinum-rhodium rods. An ultrasonic humidifier containing a piezoelectric device (functioning at $20 \mathrm{kHz}$ ) was used to generate an aerosol mist of the precursor. The mist was carried into the reaction chamber via a flow of dry dinitrogen gas, which was optimized at a flow rate of $1 \mathrm{~L} \mathrm{~min}^{-1}$.

Film Analysis Methods. XRD for thin films was carried out with a Bruker D8 Discover X-ray diffractometer using monochromatic $\mathrm{Cu} \mathrm{K} \alpha_{1}$ and $\mathrm{Cu} \mathrm{K \alpha} \alpha_{2}$ radiation of wavelengths 1.54056 and $1.54439 \AA$, respectively, emitted in an intensity ratio of $2: 1$, voltage $=40 \mathrm{kV}$; current $=40 \mathrm{~mA}$. SEM/EDXA was performed using a Philips XL30 FEG with an electron beam accelerating energy of $30 \mathrm{kV}$. XPS profiling was performed using a Thermo Scientific K-Alpha XPS system using monochromatic $\mathrm{Al} \mathrm{K} \alpha$ radiation at $1486.6 \mathrm{eV}$ X-ray source. CasaXPS software was used to analyze binding energy of the data, referenced to a $\mathrm{C} 1 \mathrm{~s}$ peak at $284.8 \mathrm{eV}$. UV/vis/NIR transmission spectra were recorded using a PerkinElmer Lambda 950 spectrometer in the range of 300$1400 \mathrm{~nm}$ with a background of air, and Tauc plots from this data were used to calculate the band gaps. Raman spectra were acquired using a Reinshaw Raman 1000 system using a helium neon laser of wavelength
$632.8 \mathrm{~nm}$ and objective lens at $50 \times$ magnification. The Raman system was calibrated against the emission lines of neon.

Synthesis of $\mathrm{Ga}\left[\mu-\left(\mathrm{OCH}_{2} \mathrm{CH}_{2} \mathrm{CH}_{2} \mathrm{NEt}_{2}\right)_{2} \mathrm{GaCl}_{2}\right]_{3}$ (1). $\mathrm{HOCH}_{2}-$ $\mathrm{CH}_{2} \mathrm{CH}_{2} \mathrm{NEt}_{2}(27.8 \mathrm{mg}, 0.21 \mathrm{mmol})$ was added to a stirred solution of $\left[\mathrm{GaCl}\left(\mathrm{NMe}_{2}\right)_{2}\right]_{2}(20.0 \mathrm{mg}, 51.7 \mu \mathrm{mol})$ in hexane $\left(20 \mathrm{~cm}^{3}\right)$ at $-78{ }^{\circ} \mathrm{C}$. The reaction mixture was left to stir for $24 \mathrm{~h}$. The solvent was then removed under reduced pressure, yielding a colorless oil of (1). Extended synthesis in the Supporting Information (SI). ${ }^{1} \mathrm{H}$ NMR $\delta$ / ppm (toluene- $\left.d_{8}\right) 25^{\circ} \mathrm{C}: 3.86\left(\mathrm{t}, 4 \mathrm{H}\left(-\mathrm{OCH}_{2}\right), J=5.82 \mathrm{~Hz}\right), 2.72(\mathrm{~m}$, $8 \mathrm{H}\left(-\mathrm{N}\left(\mathrm{CH}_{2} \mathrm{CH}_{3}\right)_{2}\right), 4 \mathrm{H}\left(-\mathrm{CH}_{2} \mathrm{~N}\right), 1.72$ (quin, $4 \mathrm{H}\left(-\mathrm{OCH}_{2} \mathrm{CH}_{2}\right), J$ $=6.18 \mathrm{~Hz}), 1.04\left(\mathrm{t}, 12 \mathrm{H},\left(-\mathrm{N}\left(\mathrm{CH}_{2} \mathrm{CH}_{3}\right)\right), J=7.14 \mathrm{~Hz}\right) .60^{\circ} \mathrm{C}: 4.07(\mathrm{~s}$, $\left.4 \mathrm{H}\left(-\mathrm{OCH}_{2}\right)\right), 2.65-2.49\left(\mathrm{~m} 8 \mathrm{H}\left(-\mathrm{N}\left(\mathrm{CH}_{2} \mathrm{CH}_{3}\right)_{2}\right), 4 \mathrm{H}\left(-\mathrm{CH}_{2} \mathrm{~N}\right)\right)$, $1.63\left(\mathrm{~s}, 4 \mathrm{H}\left(-\mathrm{OCH}_{2} \mathrm{CH}_{2}\right)\right), 1.02-0.91\left(\mathrm{~m}, 12 \mathrm{H},\left(-\mathrm{N}\left(\mathrm{CH}_{2} \mathrm{CH}_{3}\right)\right)\right)$. ${ }^{13} \mathrm{C}\left\{{ }^{1} \mathrm{H}\right\}$ NMR $\delta /$ ppm (toluene- $\left.d_{8}\right) 25{ }^{\circ} \mathrm{C}: 64.8\left(-\mathrm{OCH}_{2}\right), 52.8$ $\left(-\mathrm{CH}_{2} \mathrm{CH}_{2} \mathrm{~N}\right), 46.4\left(-\mathrm{N}\left(\mathrm{CH}_{2} \mathrm{CH}_{3}\right)_{2}\right), 38.5\left(-\mathrm{OCH}_{2} \mathrm{CH}_{2}\right), 10.1$ $\left(-\mathrm{N}\left(\mathrm{CH}_{2} \mathrm{CH}_{3}\right)_{2}\right)$. 2D NMR spectrum is included in the SI. ESI (ES-): $m / z=1273\left(\mathrm{Ga}_{4} \mathrm{Cl}_{6} \mathrm{O}_{6} \mathrm{~N}_{6} \mathrm{C}_{42} \mathrm{H}_{96}\right)$. (ES+): $414\left(\mathrm{Ga}_{2} \mathrm{Cl}_{2} \mathrm{O}_{2} \mathrm{~N}_{2}-\right.$ $\left.\mathrm{C}_{10} \mathrm{H}_{24}\right), 398\left(\mathrm{Ga}_{2} \mathrm{Cl}_{2} \mathrm{O}_{2} \mathrm{NC}_{10} \mathrm{H}_{22}\right), 133\left(\mathrm{ONC}_{7} \mathrm{H}_{19}\right)$.

Synthesis of $\left[\mathrm{GaCl}\left(\mathrm{OCH}_{2} \mathrm{CH}_{2} \mathrm{NEt}_{2}\right)_{2}\right]$ (2). $\mathrm{HOCH}_{2} \mathrm{CH}_{2} \mathrm{NEt}_{2}$ (4.69 g, $40.2 \mathrm{mmol})$ was added to a stirred solution of $\left[\mathrm{GaCl}\left(\mathrm{NMe}_{2}\right)_{2}\right]_{2}(3.79$ $\mathrm{g}, 9.80 \mathrm{mmol})$ in diethyl ether $\left(40 \mathrm{~cm}^{3}\right)$ at $-78{ }^{\circ} \mathrm{C}$. The reaction mixture was left to stir for $24 \mathrm{~h}$. The solution was then concentrated under reduced pressure to a minimum $\left(\mathrm{ca} .10 \mathrm{~cm}^{3}\right)$ and cooled to -18 ${ }^{\circ} \mathrm{C}$. Colorless crystals of $\left[\mathrm{GaCl}\left(\mathrm{OCH}_{2} \mathrm{CH}_{2} \mathrm{NEt}_{2}\right)_{2}\right]$ (2) were obtained (5.95 g, 90\%). Anal. Calcd. for $\mathrm{C}_{12} \mathrm{H}_{28} \mathrm{ClN}_{2} \mathrm{O}_{2} \mathrm{Ga}$ : C, 42.68; $\mathrm{H}, 8.36$; $\mathrm{N}$, 8.30. Found: C, $40.42 ; \mathrm{H}, 8.05 ; \mathrm{N}, 7.21 \%$. Mp: $81{ }^{\circ} \mathrm{C} .{ }^{1} \mathrm{H}$ NMR $\delta / \mathrm{ppm}$ $\left(\mathrm{CD}_{2} \mathrm{Cl}_{2}\right) 3.72\left(\mathrm{~m}, 4 \mathrm{H}\left(-\mathrm{OCH}_{2}\right)\right), 3.08\left(\mathrm{~m} 4 \mathrm{H}\left(-\mathrm{N}\left(\mathrm{CH}_{2} \mathrm{CH}_{3}\right)_{2}\right)\right)$, $2.96\left(\mathrm{~m}, 4 \mathrm{H}\left(-\mathrm{N}\left(\mathrm{CH}_{2} \mathrm{CH}_{3}\right)_{2}\right)\right), 2.65\left(\mathrm{~m}, 8 \mathrm{H}\left(-\mathrm{N}\left(\mathrm{CH}_{2} \mathrm{CH}_{3}\right)_{2}\right.\right.$ and $\left.\left.-\mathrm{OCH}_{2} \mathrm{CH}_{2}\right)\right), 1.10\left(\mathrm{t}, 6 \mathrm{H},\left(-\mathrm{N}\left(\mathrm{CH}_{2} \mathrm{CH}_{3}\right)_{2}\right) J=7.2 \mathrm{~Hz}\right), 0.96(\mathrm{t}, 6 \mathrm{H}$, $\left.\left(-\mathrm{N}\left(\mathrm{CH}_{2} \mathrm{CH}_{3}\right)_{2}\right), J=7.2 \mathrm{~Hz}\right) \cdot{ }^{13} \mathrm{C}\left\{{ }^{1} \mathrm{H}\right\}$ NMR $\delta / \mathrm{ppm}\left(\mathrm{CD}_{2} \mathrm{Cl}_{2}\right)-20$ ${ }^{\circ} \mathrm{C}: 57.9\left(-\mathrm{OCH}_{2}\right), 53.3\left(-\mathrm{OCH}_{2} \mathrm{CH}_{2}\right), 44.7\left(-\mathrm{N}\left(\mathrm{CH}_{2} \mathrm{CH}_{3}\right)_{2}\right), 40.4$ $\left(-\mathrm{N}\left(\mathrm{CH}_{2} \mathrm{CH}_{3}\right)_{2}\right), 9.3\left(-\mathrm{N}\left(\mathrm{CH}_{2} \mathrm{CH}_{3}\right)_{2}\right), 6.1\left(-\mathrm{N}\left(\mathrm{CH}_{2} \mathrm{CH}_{3}\right)_{2}\right)$. LRMS $\left(\mathrm{CI}^{+}, \mathrm{CH}_{4}\right): m / z=337\left([\mathrm{M}]^{+}\right), 301\left([\mathrm{M}-\mathrm{Cl}]^{+}\right)$.

Synthesis of $\left[\mathrm{GaCl}\left(\mathrm{OCH}_{2} \mathrm{CH}_{2} \mathrm{CH}_{2} \mathrm{NMe}_{2}\right)_{2}\right]$ (3). $\mathrm{HOCH}_{2} \mathrm{CH}_{2} \mathrm{CH}_{2-}$ $\mathrm{NMe}_{2}(2.18 \mathrm{~g}, 21.2 \mathrm{mmol})$ was added to a stirred solution of $\left[\mathrm{GaCl}\left(\mathrm{NMe}_{2}\right)_{2}\right]_{2}(2.00 \mathrm{~g}, 5.17 \mathrm{mmol})$ in diethyl ether $\left(40 \mathrm{~cm}^{3}\right)$ at -78 ${ }^{\circ} \mathrm{C}$. The reaction mixture was left to stir for $24 \mathrm{~h}$. The solution was then concentrated under reduced pressure to a minimum $\left(\mathrm{ca} .10 \mathrm{~cm}^{3}\right)$ and 
cooled to $-18{ }^{\circ} \mathrm{C}$. Colorless crystals of $\left[\mathrm{GaCl}\left(\mathrm{OCH}_{2} \mathrm{CH}_{2} \mathrm{CH}_{2}\right.\right.$ $\left.\mathrm{NMe}_{2}\right)_{2}$ ] (3) were obtained (1.13 g, 71\%). Anal. Calcd. for $\mathrm{C}_{10} \mathrm{H}_{24} \mathrm{ClGaN}_{2} \mathrm{O}_{2}$ : C, 38.79; H, 7.82; N, 9.05. Found: C, 38.19; H, 7.90; N, 8.54\%. Mp: $81{ }^{\circ} \mathrm{C} .{ }^{1} \mathrm{H}$ NMR $\delta / \mathrm{ppm}\left(\mathrm{CD}_{2} \mathrm{Cl}_{2}\right)-20{ }^{\circ} \mathrm{C}: 4.09$ $\left(\mathrm{m}, 2 \mathrm{H}\left(-\mathrm{OCH}_{2}\right)\right), 3.96\left(\mathrm{~m}, 2 \mathrm{H}\left(-\mathrm{OCH}_{2}\right)\right), 3.01(\mathrm{~m}, 2 \mathrm{H}$ $\left(-\mathrm{OCH}_{2} \mathrm{CH}_{2} \mathrm{CH}_{2}\right), 2.41\left(\mathrm{~m}, 6 \mathrm{H}\left(-\mathrm{N}\left(\mathrm{CH}_{3}\right)\right)\right.$ and $2 \mathrm{H}\left(-\mathrm{OCH}_{2} \mathrm{CH}_{2}-\right.$ $\left.\left.\mathrm{CH}_{2}\right)\right), 2.30\left(\mathrm{~s}, 6 \mathrm{H}\left(-\mathrm{N}\left(\mathrm{CH}_{3}\right)\right), 1.92\left(\mathrm{~m}, 2 \mathrm{H}\left(-\mathrm{OCH}_{2} \mathrm{CH}_{2} \mathrm{CH}_{2}\right), 1.39\right.\right.$ $\left(\mathrm{m}, 2 \mathrm{H}\left(-\mathrm{OCH}_{2} \mathrm{CH}_{2} \mathrm{CH}_{2}\right) .{ }^{13} \mathrm{C}\left\{{ }^{1} \mathrm{H}\right\} \mathrm{NMR} \delta / \mathrm{ppm}\left(\mathrm{CD}_{2} \mathrm{Cl}_{2}\right)-20{ }^{\circ} \mathrm{C}\right.$ : $66.3\left(-\mathrm{OCH}_{2}\right), 60.3\left(-\mathrm{OCH}_{2} \mathrm{CH}_{2} \mathrm{CH}_{2}\right), 47.2\left(-\mathrm{N}\left(\mathrm{CH}_{3}\right), 44.2\right.$ $\left(-\mathrm{N}\left(\mathrm{CH}_{3}\right), 28.5\left(\mathrm{CH}_{2} \mathrm{CH}_{2} \mathrm{CH}_{2}\right)\right.$. LRMS $\left(\mathrm{CI}^{+}, \mathrm{CH}_{4}\right): \mathrm{m} / z=309$ $([\mathrm{M}]+)$.

\section{RESULTS AND DISCUSSION}

Compound Synthesis. The synthesis of 1, 2, and 3 outlined in Scheme 1 was carried out based on a modified literature procedure. ${ }^{27}$ The reaction of $\left[\mathrm{GaCl}\left(\mathrm{NMe}_{2}\right)_{2}\right]_{2}$ with 4 mol equiv

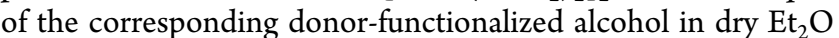
at $-78^{\circ} \mathrm{C}$ was allowed to warm to room temperature and stirred for $24 \mathrm{~h}$. This solution was then reduced in vacuo and stored in a freezer at $-18{ }^{\circ} \mathrm{C}$, affording a pale viscous oil in the case of $\mathbf{1}$ and colorless single crystals of $\mathbf{2}$ and $\mathbf{3 .}$

The reaction of 3 equiv of gallium chloride bis(dimethylamide) with 6 equiv of $\mathrm{HOCH}_{2} \mathrm{CH}_{2} \mathrm{CH}_{2} \mathrm{NEt}_{2}$ formed the oligomer 1. Several attempts to isolate a monomer were unsuccessful (detailed in SI). In the ${ }^{1} \mathrm{H}$ spectrum of $\mathbf{1}$ recorded at room temperature in $\mathrm{CD}_{2} \mathrm{Cl}_{2}(\mathrm{SI})$, the methylene protons do not show nonequivalence, resonating at the same frequency, which suggests that the $\mathrm{OCH}_{2} \mathrm{CH}_{2} \mathrm{CH}_{2} \mathrm{NEt}_{2}$ fragment has not formed a ring-like structure and remained as an open chain with $\mu-2$ bridging oxygens and the rest of the alcohol as a nondonating pendant. Cooling led to a large number of broad lines in the $\mathrm{CD}_{2} \mathrm{Cl}_{2}$ spectrum. Such spectral behavior is different from that observed for $\mathbf{2}$ and $\mathbf{3}$ (see below) and is indicative of complex multisite exchange. Both positive and negative ESI conditions were used to help identify possible fragments from oligomer 1. Under ESI conditions, possible oxonium/ ammonium species could be detected in the positive mode, or oxygen/nitrogen anions in the negative mode. Mass spectrometry of 1 showed a specific isotopic pattern of 11 peaks, with the highest molecular ion fragment containing four gallium and six chlorine atoms occurring at $1279 \mathrm{~m} / z$. The expected molecular ion fragment of the proposed structure of $\mathrm{Ga}\left[\mu-\left(\mathrm{OCH}_{2} \mathrm{CH}_{2}\right.\right.$ $\left.\left.\mathrm{CH}_{2} \mathrm{NEt}_{2}\right)_{2} \mathrm{GaCl}_{2}\right]_{3}$ can be found at $1273 \mathrm{~m} / z$; however, under ESI conditions, it is possible that protonated alcohol sites caused by the ESI solvent could have given rise to the mass of $1279 \mathrm{~m} / \mathrm{z}$. Other fragments containing specific isotopic patterns for two gallium and chlorine atoms in the positive mode at 414 and 398 $\mathrm{m} / z$ suggested heteroatom uncoupling between the nitrogen and ethyl groups or alkyl backbone, respectively, which is not uncommon under mass spectrometry conditions and similar to other group 13 alkoxide species previously reported in the literature. ${ }^{37-40}$

In order to probe this interesting reactivity, the reaction of 3 equiv of gallium chloride bis(dimethylamide) with 12 equiv of the smaller backbone donor-functionalized alcohol HO$\mathrm{CH}_{2} \mathrm{CH}_{2} \mathrm{NEt}_{2}$ gave crystalline material in excellent yield (90\%) which was suitable for single crystal X-ray analysis. Compound 2 crystallized in the monoclinic $P 2_{1} / c$ space group, and as shown in Figure 2, it is comparable to similar gallium chlorido bis(alkoxides) previously reported. ${ }^{27}$ This alteration of the chain length from $\mathrm{HOCH}_{2} \mathrm{CH}_{2} \mathrm{CH}_{2} \mathrm{NEt}_{2}$ (used in the synthesis of $\mathbf{1}$ ) to $\mathrm{HOCH}_{2} \mathrm{CH}_{2} \mathrm{NEt}_{2}$ successfully facilitated the isolation of a monomer with the gallium atom adopting a distorted trigonal bipyramidal geometry, which is similar

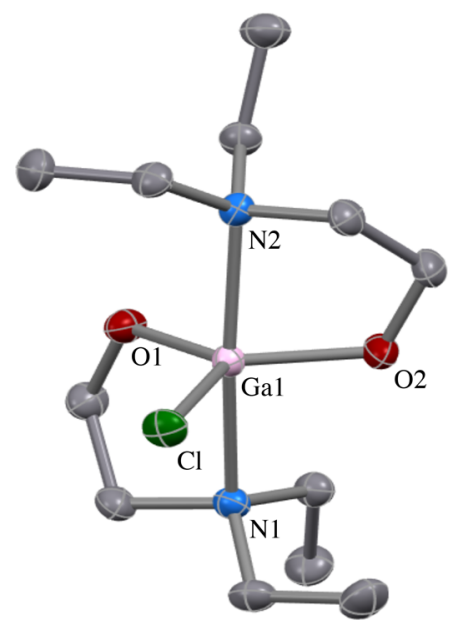

Figure 2. Molecular structure of compound 2. Thermal ellipsoids at $50 \%$ probability, hydrogen atoms omitted for clarity.

compared to the previously reported analogous gallium chloride bis(alkoxide) with the formula $\left[\mathrm{GaCl}\left(\mathrm{OCH}_{2} \mathrm{CH}_{2} \mathrm{NMe}_{2}\right)_{2}\right]$, which crystallized in the orthorhombic $\mathrm{Pna2}_{1}$ space group. ${ }^{41}$ This compound was also monomeric, and similarly adopted a trigonal bipyramidal geometry, with $-\mathrm{NMe}_{2}$ groups lying in the axial positions, and oxygen atoms of each ligand and the chlorine atom residing in the axial positions. ${ }^{41}$

In compound 2, the oxygen atoms of each alkoxide ligand as well as the chloride occupy the equatorial positions while the nitrogen atoms of the donor-functionalized group reside in the axial positions, typical for compounds of this type. The donorfunctionalized alkoxide ligands form a five-membered ring with the gallium center. The $\mathrm{N}(1)-\mathrm{Ga}(1)-\mathrm{N}(2)$ bond angle is $170.36(5)^{\circ}$, deviating from $180^{\circ}$. The sum of the bond angles in the equatorial plane of $\mathbf{2}$ is $359.95^{\circ}$ and hence planar. The two equatorial $\mathrm{Ga}-\mathrm{O}$ bond lengths (Table 1) are less alike than when compared to the analogous compound with methyl groups at the $\mathrm{N}$ position, $\left[\mathrm{GaCl}\left(\mathrm{OCH}_{2} \mathrm{CH}_{2} \mathrm{NMe}_{2}\right)_{2}\right](1.8235(13)$ and $1.8302(14) \AA){ }^{41}$

The Ga-N distances are 2.1802(14) and 2.2073(15) $\AA$ and are significantly shorter than the sum of the van der Waals radii;

Table 1. Selected Bond Lengths $(\AA)$ and Angles (deg) for Compounds 2 and 3

\begin{tabular}{lll} 
& \multicolumn{1}{c}{$\mathbf{2}$} & \multicolumn{1}{c}{3} \\
lengths $(\AA)$ & & \\
$\mathrm{M}-\mathrm{O}$ & $1.8339(13)$ & $1.8235(13)$ \\
& $1.8403(12)$ & $1.8302(14)$ \\
$\mathrm{M}-\mathrm{N}$ & $2.1802(14)$ & $2.2109(17)$ \\
& $2.2073(15)$ & $2.1725(16)$ \\
$\mathrm{M}-\mathrm{Cl}$ & $2.2324(5)$ & $2.2296(6)$ \\
angles $(\mathrm{deg})$ & & \\
$\mathrm{O}-\mathrm{M}-\mathrm{O}$ & $127.64(6)$ & $129.34(6)$ \\
$\mathrm{N}-\mathrm{M}-\mathrm{N}$ & $170.36(5)$ & $171.32(6)$ \\
$\mathrm{O}-\mathrm{M}-\mathrm{N}$ & $85.08(5)$ & $88.50(6)$ \\
& $90.66(6)$ & $86.83(6)$ \\
& $92.34(5)$ & $88.16(6)$ \\
$\mathrm{Cl}-\mathrm{M}-\mathrm{O}$ & $83.41(5)$ & $89.19(6)$ \\
& $115.10(4)$ & $114.89(5)$ \\
$\mathrm{Cl}-\mathrm{M}-\mathrm{N}$ & $117.21(5)$ & $115.74(5)$ \\
& $95.16(4)$ & $93.76(5)$ \\
& $94.48(4)$ & $94.92(5)$
\end{tabular}


hence, these $\mathrm{Ga}-\mathrm{N}$ interactions can be considered dative. The degree of trigonality, $\tau$, is a measure of distortion for a fivecoordinate complex between the two ideals of either a squarebased pyramidal $(\tau=0)$ or a trigonal bipyramidal $(\tau=1)$ geometry. ${ }^{42}$ For compound 2, $\tau=0.71$, suggesting that the metal center is deviated severely away from a trigonal planar geometry.

Both the $\mathrm{OCH}_{2}$ and $\mathrm{NCH}_{2}$ methylene protons of the $\mathrm{OCH}_{2} \mathrm{CH}_{2} \mathrm{~N}$ fragment of the donor-functionalized ligand of 2 resonate at two different frequencies in the low-temperature ${ }^{1} \mathrm{H}$ NMR spectrum recorded at $228 \mathrm{~K}$ (SI). In addition, the methylene protons of the $\mathrm{N}\left(\mathrm{CH}_{2} \mathrm{CH}_{3}\right)_{2}$ groups resonate at two different frequencies in the same spectrum (SI). The nonequivalence of all the methylene protons in 2 at $228 \mathrm{~K}$ is attributed to the formation of a five-membered ring as a result of the coordination from the $\mathrm{O}$ and $\mathrm{N}$ heteroatoms of the bidentate ligand $\mathrm{OCH}_{2} \mathrm{CH}_{2} \mathrm{NEt}_{2}$ to the $\mathrm{Ga}$ atom. As this cycle is nonplanar (SI), the pseudo-axial and pseudo-equatorial orientations of methylene protons in the slow exchange regime on the NMR time scale at $228 \mathrm{~K}$ are expected to lead to their nonequivalence in the ${ }^{1} \mathrm{H}$ NMR spectrum.

Since compound $\mathbf{2}$ was successfully isolated as a monomer due to the decrease in the chain length of the carbon backbone (c.f. compound 1), the next variable to investigate was the substituent on the donor $\mathrm{N}$ atom. The reaction of 3 equiv of gallium chloride bis(dimethylamide) with 12 equiv of $\mathrm{HO}$ $\mathrm{CH}_{2} \mathrm{CH}_{2} \mathrm{CH}_{2} \mathrm{NMe}_{2}$ gave the monomer 3 in good yield (71\%), with $\mathrm{X}$-ray quality single crystals being isolated (Figure 3, Table 2).

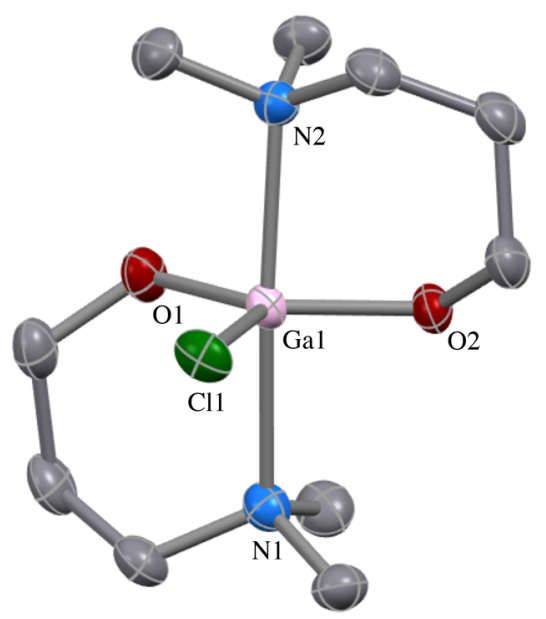

Figure 3. Molecular structure of compound 3. Thermal ellipsoids at $50 \%$ probability, hydrogen atoms omitted for clarity.

The oxygen atoms of each alkoxide ligand and the chloride group occupy the equatorial positions while the nitrogen atoms of the donor-functionalized group reside in the axial positions, despite the lengthening of the carbon backbone. The donorfunctionalized alkoxide ligands form a six-membered ring with the gallium center. The $\mathrm{N}(1)-\mathrm{Ga}(1)-\mathrm{N}(2)$ bond angle is $171.32(6)^{\circ}$, again slightly deviating from $180^{\circ}$. The sum of the bond angles in the equatorial plane of 3 are planar $\left(359.97^{\circ}\right)$.

When compared directly to compound 2 , the $\mathrm{Ga}-\mathrm{O} 1$ and $\mathrm{Ga}-\mathrm{O} 2$ bond lengths were significantly different, with the $\mathrm{Ga}-$ $\mathrm{O} 1$ and $\mathrm{Ga}-\mathrm{O} 2$ bond lengths in 3 being shorter (Table 1). This is likely due to the longer backbone relieving strain in the ( $-\mathrm{GaOCH}_{2} \mathrm{CH}_{2} \mathrm{CH}_{2} \mathrm{NMe}_{2}-$ ) ring system. The $\mathrm{Ga}-\mathrm{N}$ distances are 2.2109(17) and 2.1725(16) $\AA$, which are again
Table 2. Crystallographic Data for Compounds 2 and 3

\begin{tabular}{|c|c|c|}
\hline & 2 & 3 \\
\hline chemical formula & {$\left[\mathrm{GaClC}_{12} \mathrm{H}_{28} \mathrm{O}_{2} \mathrm{~N}_{2}\right]$} & {$\left[\mathrm{GaClC}_{10} \mathrm{H}_{24} \mathrm{O}_{2} \mathrm{~N}_{2}\right]$} \\
\hline $\mathrm{Fw}\left(\mathrm{g} \mathrm{mol}^{-1}\right)$ & 337.53 & 309.48 \\
\hline crystal system & monoclinic & monoclinic \\
\hline space group & $P 2_{1} / c$ & $P 2_{1} / c$ \\
\hline$a(\AA)$ & $15.924(2)$ & $10.0997(17)$ \\
\hline$b(\AA)$ & $7.0297(9)$ & $9.9824(17)$ \\
\hline$c(\AA)$ & $15.4616(19)$ & $15.543(2)$ \\
\hline$\alpha(\mathrm{deg})$ & 90 & 90 \\
\hline$\beta(\mathrm{deg})$ & $114.538(2)$ & $113.718(9)$ \\
\hline$\gamma(\operatorname{deg})$ & 90 & 90 \\
\hline$V\left(\AA^{3}\right)$ & $1574.5(3)$ & $1434.7(4)$ \\
\hline$Z$ & 4 & 4 \\
\hline$\rho_{\text {calcd }}\left(\mathrm{g} \mathrm{cm}^{-3}\right)$ & 1.424 & 1.433 \\
\hline$\mu\left(\mathrm{mm}^{-1}\right)$ & 1.915 & 2.094 \\
\hline reflns collected & 12615 & 11541 \\
\hline unique reflns & 3676 & 3362 \\
\hline$R_{\text {int }}$ & 0.0354 & 0.0317 \\
\hline$R_{1}$ and $w R_{2}[I>2 \sigma(I)]$ & $0.0304,0.0776$ & $0.0325,0.0853$ \\
\hline$R_{1}$ and $w R_{2}$ [all data $]$ & $0.0343,0.0800$ & $0.0406,0.0901$ \\
\hline
\end{tabular}

significantly shorter than the sum of the van der Waals radii; therefore, these $\mathrm{Ga}-\mathrm{N}$ interactions can be considered dative. For compound 3, $\tau=0.70$, suggesting again that the metal center is severely distorted away from an ideal trigonal planar geometry.

NMR and DFT Study. Featureless broad lines, implying a fluxional coordination sphere, were observed in the ${ }^{1} \mathrm{H}$ NMR spectrum at $296 \mathrm{~K}$ of compound 3. On cooling, the spectrum sharpened significantly at $207 \mathrm{~K}$ (Figure 4) to show a spectrum analogous to that observed for 2 at $228 \mathrm{~K}$ (see SI).

The nonequivalent pairs of signals observed clearly in the lowtemperature ${ }^{1} \mathrm{H}$ NMR spectra of $\mathbf{3}$ can be seen to coalesce as the temperature was raised (Figure 4). Coalescence is defined as the temperature at which a single peak with a flat top is observed, which can be seen in Figure 5. The temperature dependence of the NMR spectrum of the $\mathrm{NMe}_{2}$ protons showing two singlets at 2.25 and $2.35 \mathrm{ppm}$ at $207 \mathrm{~K}$ provides convenient means to follow the chemical exchange process as a function of temperature (Figure 5) and estimate the free energy of activation. Using the chemical shift difference value of $40 \mathrm{~Hz}$ at $213 \mathrm{~K}$ and the standard expression (eq 1 )

$$
k=\frac{k_{\mathrm{B}} T}{h} \mathrm{e}^{-\Delta G^{\ddagger} / R T}
$$

(where $k$ is the rate constant, $k_{\mathrm{B}}$ is Boltzmann's constant, $T$ is the coalescence temperature, $h$ is Planck's constant, and $\Delta G^{\ddagger}$ is the Gibbs free energy of activation) for an equally populated twosite exchange model, ${ }^{43}$ the free energy of activation $\left(\Delta G^{\ddagger}\right)$ at the coalescence temperature of $256 \mathrm{~K}$ (Figure 5) is estimated to be $53 \pm 1 \mathrm{~kJ} \mathrm{~mol}^{-1}$.

The fluxionality due to the hemilabile coordination of the donor-functionalized alkoxide ligands can cause the nitrogen and gallium atoms to dissociate-associate in a dynamic fashion, producing the broad spectrum observed at $296 \mathrm{~K}$ (Figure 4). This fluxionality displayed by compounds 2 and 3 is not surprising; five-coordinate trigonal bipyramidal systems are capable of polytopal rearrangements in the coordination sphere, classically portrayed by $\mathrm{PF}_{5}$, with more modern examples including titanium, cobalt, iron, and antimony complexes. ${ }^{44-47}$ Following these types of rearrangements, bidentate ligands with weakly coordinated donor groups lying in the axial positions 


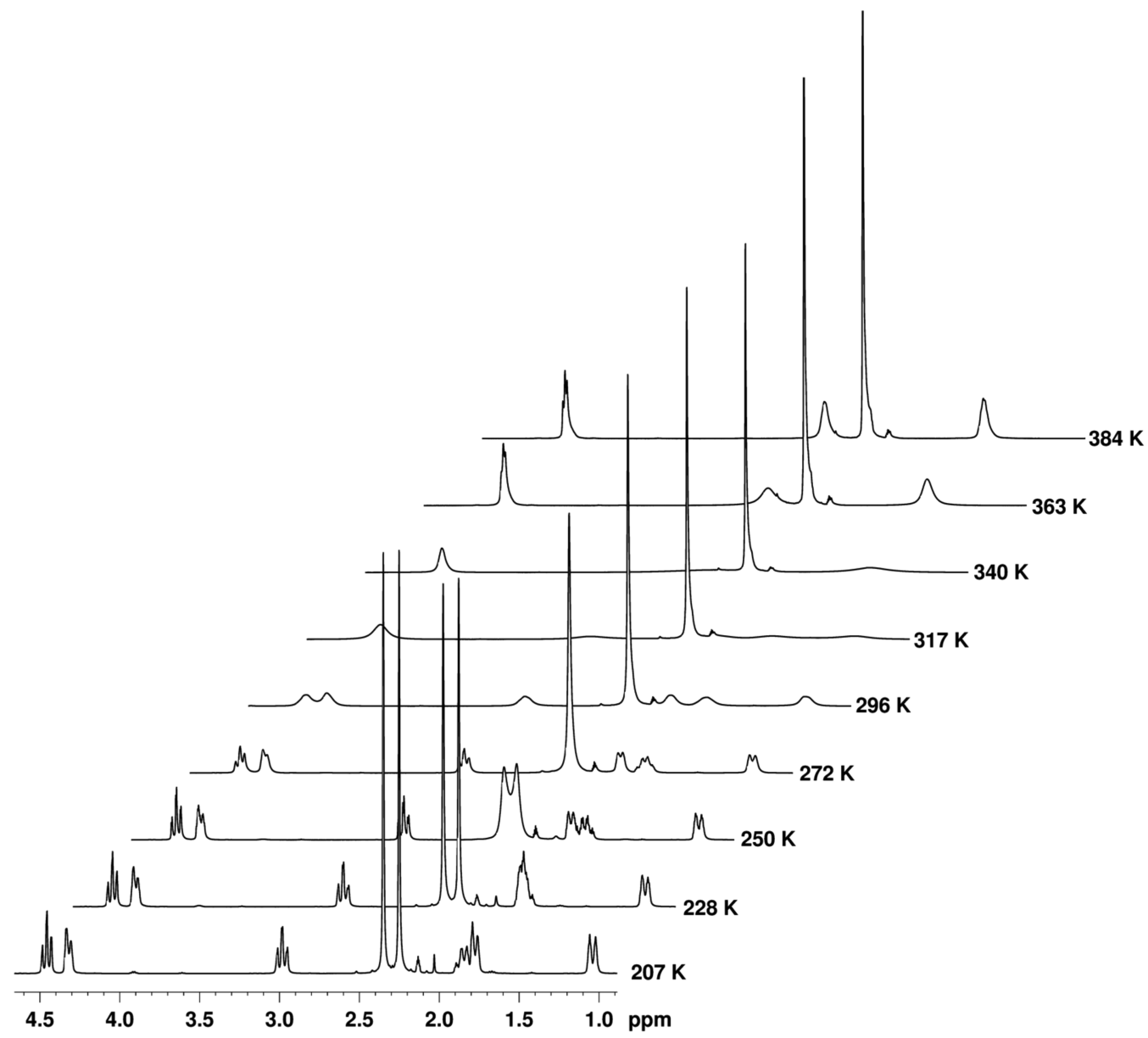

Figure 4. VT-NMR of compound 3 in toluene- $d_{8}$ over a temperature range from 207 to $384 \mathrm{~K}$. Spectra have been staggered for clarity.

could plausibly undergo dissociation, when bound to a labile metal center-in this case, gallium(III). This disconnection from either one or both of the hemilabile alkoxide ligands allows an inversion of the configuration at the metal center, followed by reattachment of the two nitrogen-donor groups. On the basis of the X-ray structure of 3 and the 1:1 ratio of the two dynamically exchanging species observed at low temperatures from the NMR spectra in toluene- $d_{8}$ (Figures 4 and 5), a possible solution-state exchange pathway is shown in Figure 6 using the DFT M06/ def2-TZVP optimized geometries (Gaussian 09). ${ }^{48}$

The symmetry of $\mathbf{3 b}$ corresponds to that determined by single crystal X-ray diffraction in the solid state. On the assumption that the Ga $\cdots \mathrm{N}$ close contacts can be considered as bonds in 3, two six-membered rings in their chair conformations can be visualized with a common Ga atom (Figure 6). Then, a possible mechanism, by which the rearrangement shown in Figure 6 can occur, involves interconversions of the six-membered rings (depicted as an exchange between 3a to 3c in Figure 6), followed by rotations about the $\mathrm{O}-\mathrm{Ga}$ bonds (depicted as an exchange between $3 c$ to $3 b$ in Figure 6 ). The calculated free energy of $3 c$ relative to $3 \mathbf{a}$ (and $3 \mathbf{b}$ ) is $+13.3 \mathrm{~kJ} \mathrm{~mol}^{-1}$ at the M06/def2-TZVP level of theory, suggesting that the presence of a very small proportion of $3 \mathrm{c}$ in solution cannot be ruled out, hence supporting the possibility of the above considered mechanism in Figure 6. Other possible mechanisms such as direct interconversion of the two six-membered rings, involving the ligands sweeping over or around the metal center, are also possible, although they may be energetically less likely.
This deviation from the structural assignment resolved by $\mathrm{X}$ ray single crystal analysis has also been reported by Nguyen et al. $^{49}$ in which thiolate ligands are rapidly exchanged around a gallium center between bridging and terminal positions in solution and is confirmed with low-temperature NMR experiments. To summarize, the 2-carbon backbone in compound 2 shows some fluxionality, and when moving to a 3-carbon backbone in 3 , the fluxionality is increased. When comparing to 1 which also has a 3 -carbon backbone, as well as an $-\mathrm{NEt}_{2}$ group rather than the $-\mathrm{NMe}_{2}$ group in 3, the fluxionality is increased such that oligomerization occurs instead, and a monomer cannot be isolated. Given the monomeric nature of $\mathbf{2}$ and 3, these two compounds were investigated further as precursors for the CVD of $\mathrm{Ga}_{2} \mathrm{O}_{3}$

AACVD Experiments. The monomeric compounds 2 and 3 were successfully used to deposit $\mathrm{Ga}_{2} \mathrm{O}_{3}$ at an optimized temperature of $450{ }^{\circ} \mathrm{C}$. A dinitrogen carrier gas was used at $1 \mathrm{~L}$ $\min ^{-1}$ to deliver the aerosol of either 2 or 3 using dry toluene as the solvent. Table 3 shows the deposition conditions used and the resulting properties of the films from each of the precursor.

Transmittance and band gap calculations of the annealed thin films are displayed in Table 3 Optical measurements were conducted over a range from 250 to $2000 \mathrm{~nm}$ on quartz samples. Measurements for glass samples are not reported as the transmittance for glass overlaps with that of $\mathrm{Ga}_{2} \mathrm{O}_{3}$. Transmittance measurements revealed the annealed $\mathrm{Ga}_{2} \mathrm{O}_{3}$ thin films transmitted $74-75 \%$ of visible light $(380-780 \mathrm{~nm})$ compared to $76 \%$ of plain quartz. 

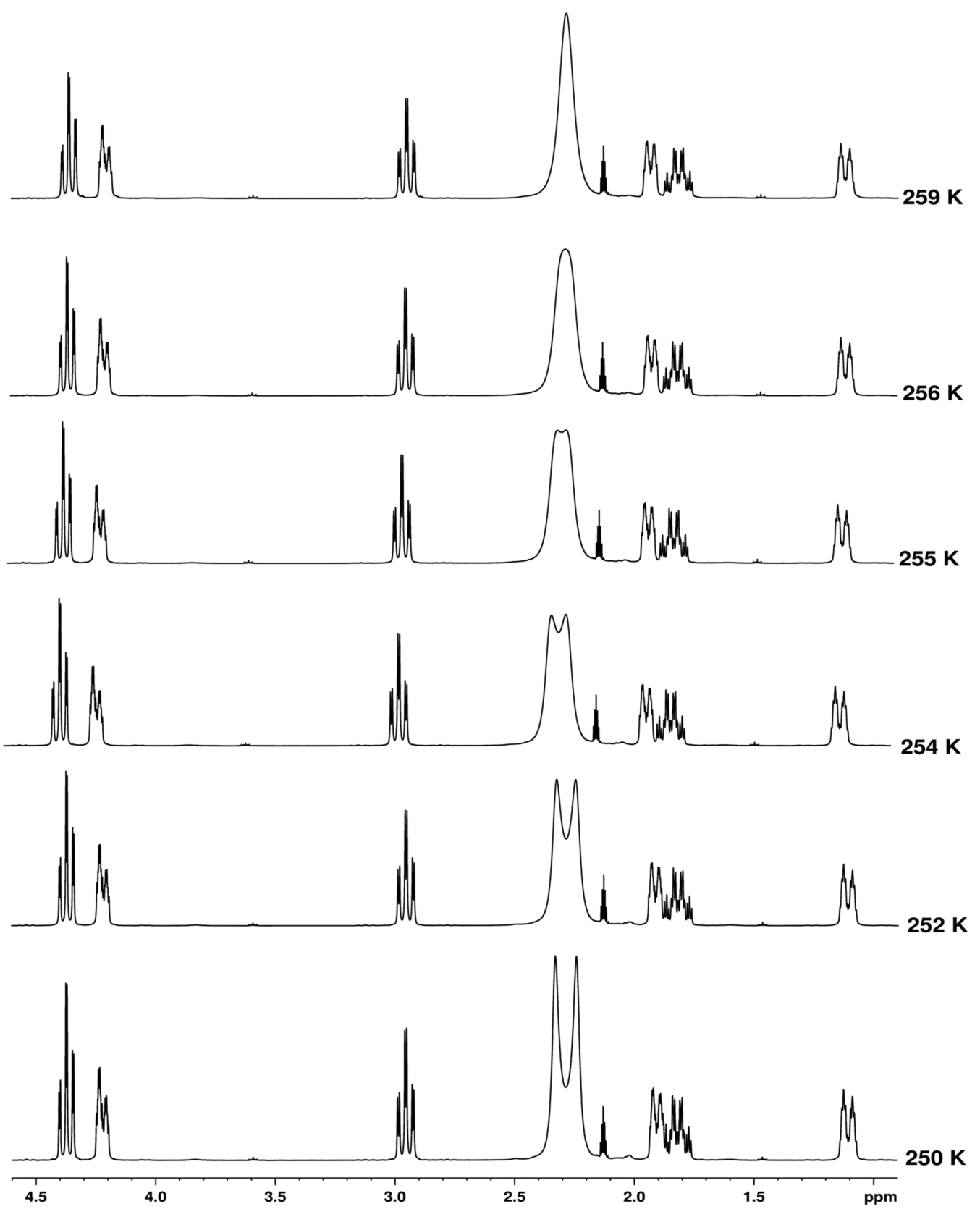

Figure 5. VT-NMR of 3 in toluene- $d_{8}$ over a temperature range from 250 to $259 \mathrm{~K}$ used to determine the coalescence temperature.

Films grown on silica coated float glass from 2 and 3 were amorphous; energy dispersive X-ray analysis (EDXA) confirmed negligible carbon contamination $(<0.1$ atm $\%)$, also confirmed by Raman spectroscopy (SI). The composition of the annealed films was also determined by EDXA measurements, the results of which indicated the presence of oxygen, gallium, and carbon. The presence of gallium and oxygen in a 1:1.5 ratio confirmed the $\mathrm{Ga}_{2} \mathrm{O}_{3}$ stoichiometry. The presence of residual chlorine or nitrogen was not observed. To obtain crystalline $\mathrm{Ga}_{2} \mathrm{O}_{3}$ material, films deposited from 2 on quartz substrates were annealed at $1000{ }^{\circ} \mathrm{C}$ for $12 \mathrm{~h}$ in air. Glancing angle X-ray powder diffraction confirmed that the annealing process gave crystalline films, consistent with reference standards for monoclinic $\beta-\mathrm{Ga}_{2} \mathrm{O}_{3}$ (Figure 7).

SEM analysis was conducted on both the as-deposited and annealed thin films. SEM images of $\mathrm{Ga}_{2} \mathrm{O}_{3}$ thin films deposited from precursors $\mathbf{2}$ and $\mathbf{3}$ are shown in Figure 8a,b. As-deposited
$\mathrm{Ga}_{2} \mathrm{O}_{3}$ samples were seen to have a very smooth morphology. Features were barely visible with particle sizes ranging from 10 to $30 \mathrm{~nm}$. After annealing, the crystallite size increased to $100 \mathrm{~nm}$, which is expected as annealing causes the film to sinter (see SI for a histogram of the distribution of the grain size). Side-on SEM measurements were used to determine the film thickness $(\sim 10 \mu \mathrm{m})$ and displayed a uniform thickness along the entire edge of the glass substrate (SI). Additionally, the X-ray photoelectron spectroscopy (XPS) for a $\mathrm{Ga}_{2} \mathrm{O}_{3}$ thin film deposited from compound 3 (Figure 8c) confirmed the presence of gallium in the thin films.

\section{CONCLUSIONS}

Gallium chlorido bis(alkoxide) precursors (1-3) were synthesized with monomer formation in the case of $\mathbf{2}$ and 3 , and oligomer formation in $\mathbf{1}$. In all cases, the synthetic route to these compounds involved the reaction of a gallium chlorido 

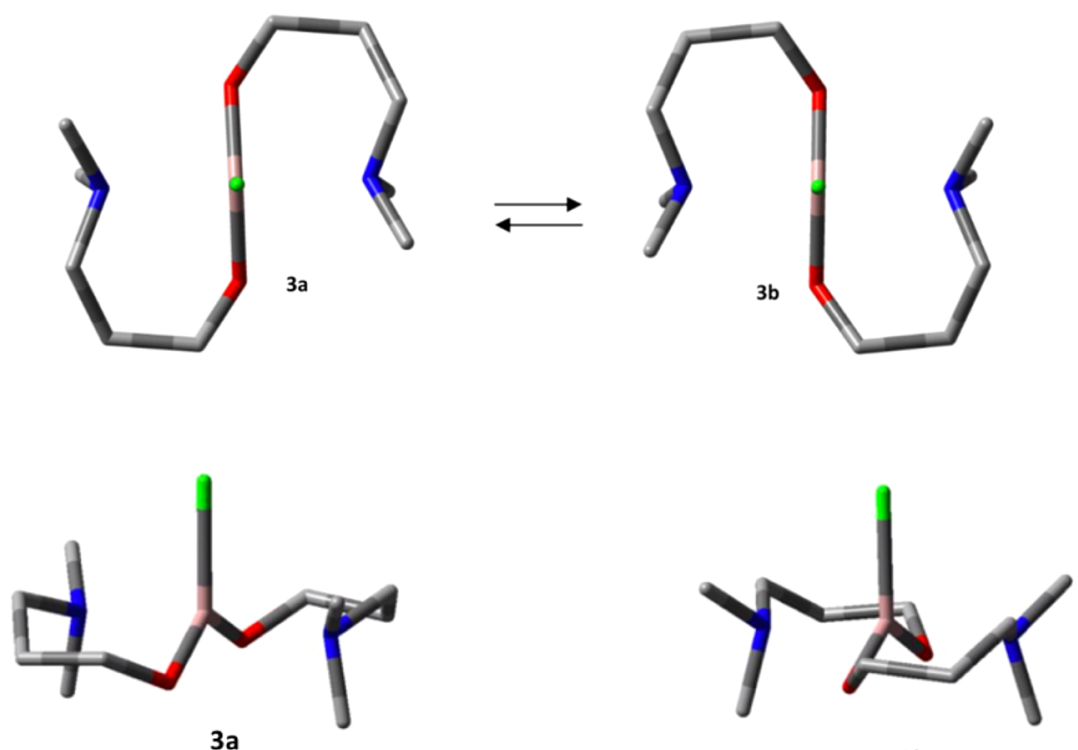

3a
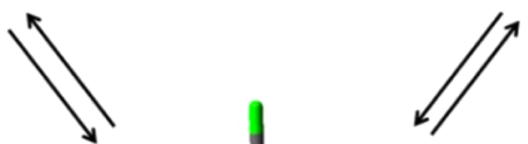

$3 \mathrm{~b}$

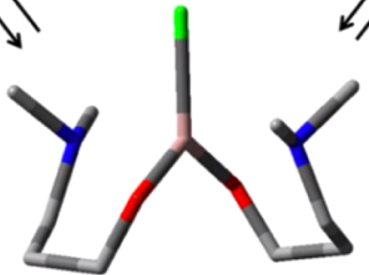

$3 c$

Figure 6. Dynamic behavior of the alkoxide ligand arms in 3, illustrated using DFT optimized molecular geometries. Conformation 3a is viewed along the $\mathrm{Cl}-\mathrm{Ga}$ axis (top left), and from the side (middle left). Conformation $\mathbf{3 b}$ is viewed along the $\mathrm{Cl}$-Ga axis (top right) and from the side (middle right). Conformation $3 \mathrm{c}$ is viewed from the side (bottom). Color key: gallium, pink; chlorine, green; oxygen, red; nitrogen, blue; carbon, gray.

Table 3. AACVD Conditions and $\mathrm{Ga}_{2} \mathrm{O}_{3}$ Thin Film Properties Derived from UV/vis Data Deposited from Compounds 2 and 3

\begin{tabular}{cccc} 
precursor & temperature $\left({ }^{\circ} \mathrm{C}\right)$ & transmittance $(\%)$ & band gap $(\mathrm{eV})$ \\
\hline $\mathbf{2}$ & 450 & 75 & 3.8 \\
$\mathbf{3}$ & 450 & 74 & 3.7
\end{tabular}

dimethylamide dimer with 4 mol equiv of the corresponding functionalized alcohol. The anticipated fluxionality of compounds 2 and 3 in solution was probed and confirmed by VTNMR measurements. The fluxionality trend observed in the synthesis of these precursors suggested that increasing the ligand backbone length and the size of the substituents on $\mathrm{N}$ leads to increased dynamic behavior. The result of this implied a long-

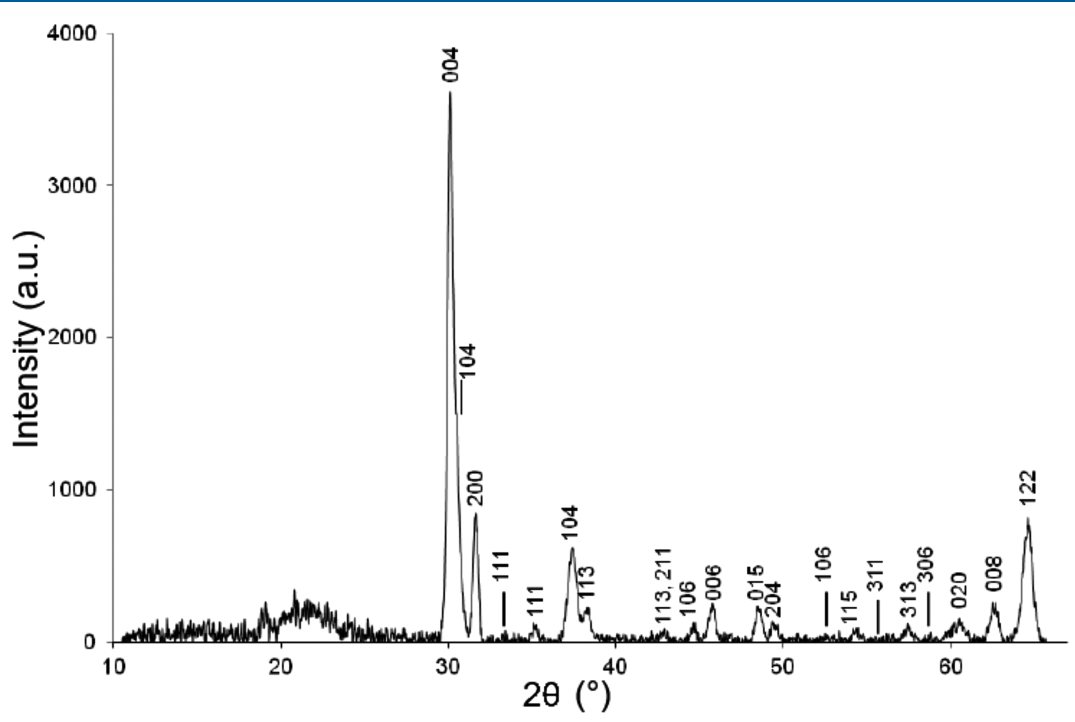

Figure 7. XRD pattern of the monoclinic $\beta-\mathrm{Ga}_{2} \mathrm{O}_{3}$ film deposited on quartz by AACVD of compound 2 after annealing at $1000{ }^{\circ} \mathrm{C}$ for $12 \mathrm{~h}$. 

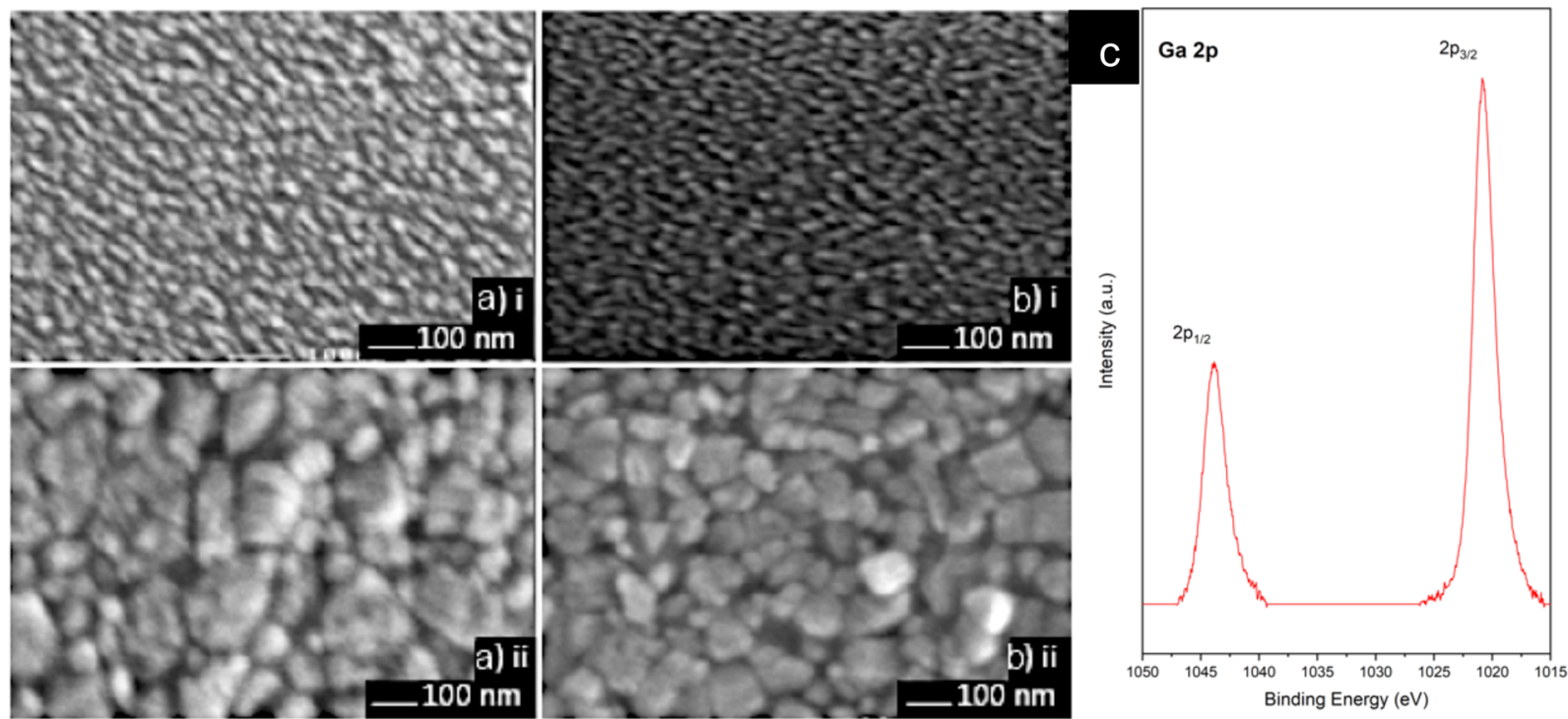

Figure 8. SEM images of gallium oxide thin films (a) 2 and (b) 3 deposited by AACVD in toluene at $450{ }^{\circ} \mathrm{C}$. Images $(x)$ i show the as-deposited amorphous films on silica coated float glass. Images $(x)$ ii show the annealed films on quartz. (c) XPS of Ga $2 p$ for a Ga $\mathrm{O}_{3}$ thin film deposited from compound 3.

chain backbone with bulky $\mathrm{N}$ substituents, as is the case for $\mathbf{1}$, provides so much flexibility that no monomeric unit was formed. Contrastingly, a smaller backbone (2) afforded some fluxionality and could be isolated as a monomer, whereas smaller $\mathrm{N}$ substituents (3) afforded a highly fluxional monomeric compound. In order to understand how 3 exhibits highly fluxional behavior in solution, DFT calculations were also carried out to consider a possible mechanism behind the observed fluxionality in 3 . Compounds 2 and 3 were used to successfully deposit $\mathrm{Ga}_{2} \mathrm{O}_{3}$ via $\mathrm{AACVD}$ at an optimized temperature of $450{ }^{\circ} \mathrm{C}$ to give the expected amorphous material which could be annealed at $1000{ }^{\circ} \mathrm{C}$ to give crystalline gallium oxide.

\section{ASSOCIATED CONTENT}

\section{(S) Supporting Information}

The Supporting Information is available free of charge on the ACS Publications website at DOI: 10.1021/acs.inorgchem.9b01496.

Experimental and spectroscopic details for the attempted alternative routes to compound $\mathbf{1}$ and 2D NMR spectra (PDF)

\section{Accession Codes}

CCDC 1917612 and 1917613 contain the supplementary crystallographic data for this paper. These data can be obtained free of charge via www.ccdc.cam.ac.uk/data_request/cif, or by emailing data_request@ccdc.cam.ac.uk, or by contacting The Cambridge Crystallographic Data Centre, 12 Union Road, Cambridge CB2 1EZ, UK; fax: +44 1223336033.

\section{AUTHOR INFORMATION}

\section{Corresponding Author}

*E-mail: c.j.carmalt@ucl.ac.uk.

\section{ORCID $\odot$}

Caroline E. Knapp: 0000-0003-4219-9313

Claire J. Carmalt: 0000-0003-1788-6971

\section{Notes}

The authors declare no competing financial interest.

\section{ACKNOWLEDGMENTS}

We would like to thank the EPSRC (grant nos. EP/F035675/1 and EP/P020410/1) and Pilkington NSG for supplying the glass substrates. We would like to thank Ms. Malavika Bhide for carrying out SEM measurements and Dr. Tom Macdonald for carrying out Raman spectroscopy measurements on the deposited thin films.

\section{REFERENCES}

(1) Yu, H.; Yeom, H.-I.; Lee, J. W.; Lee, K.; Hwang, D.; Yun, J.; Ryu, J.; Lee, J.; Bae, S.; Kim, S. K.; Jang, J. Superfast Room-Temperature Activation of $\mathrm{SnO}_{2}$ Thin Films via Atmospheric Plasma Oxidation and Their Application in Planar Perovskite Photovoltaics. Adv. Mater. 2018, 30 (10), 1704825.

(2) Sankarasubramanian, K.; Soundarrajan, P.; Logu, T.; Sethuraman, K.; Ramamurthi, K. Enhancing Resistive-Type Hydrogen Gas Sensing Properties of Cadmium Oxide Thin Films by Copper Doping. New J. Chem. 2018, 42 (2), 1457-1466.

(3) Mallick, A.; Basak, D. Revisiting the Electrical and Optical Transmission Properties of Co-Doped $\mathrm{ZnO}$ Thin Films as n-Type TCOs. Prog. Mater. Sci. 2018, 96, 86-110.

(4) Liu, H.; Peng, J.; Liu, W.; Wang, Y.; Wu, J.; Zhang, G.; Wang, X.; Yan, Y. Strong Interference-Based Ultrathin Conductive AntiReflection Coating on Metal Substrates for Optoelectronics. NPG Asia Mater. 2018, 10, 309-317.

(5) Kong, L.; Ma, J.; Luan, C.; Mi, W.; Lv, Y. Structural and Optical Properties of Heteroepitaxial Beta $\mathrm{Ga}_{2} \mathrm{O}_{3}$ Films Grown on MgO (100) Substrates. Thin Solid Films 2012, 520, 4270-4274.

(6) Arnold, S. P.; Prokes, S. M.; Perkins, F. K.; Zaghloul, M. E. Design and Performance of a Simple, Room-Temperature Nanowire Gas Sensor. Appl. Phys. Lett. 2009, 95, 103102.

(7) Oh, S.; Kim, J.; Ren, F.; Pearton, S. J.; Kim, J. Quasi-TwoDimensional,-Gallium Oxide Solar-Blind Photodetectors with Ultrahigh Responsivity. J. Mater. Chem. C 2016, 4, 9245-9250.

(8) Korotcenkov, G.; Cho, B. K. Metal Oxide Composites in Conductometric Gas Sensors: Achievements and Challenges. Sens. Actuators, B 2017, 244, 182-210.

(9) Knapp, C. E.; Carmalt, C. J. Solution Based CVD of Main Group Materials. Chem. Soc. Rev. 2016, 45 (4), 1036-1064.

(10) Basharat, S.; Carmalt, C. J.; Binions, R.; Palgrave, R.; Parkin, I. P. Gallium Oxide Thin Films from the AACVD of $\left[\mathrm{Ga}\left(\mathrm{NMe}_{2}\right)_{3}\right]_{2}$ and Donor Functionalised Alcohols. Dalt. Trans. 2008, No. 5, 591. 
(11) Bloor, L. G.; Carmalt, C. J.; Pugh, D. Single-Source Precursors to Gallium and Indium Oxide Thin Films. Coord. Chem. Rev. 2011, 255, $1293-1318$.

(12) Knapp, C. E.; Prassides, I. D.; Sathasivam, S.; Parkin, I. P.; Carmalt, C. J. Aerosol-Assisted Chemical Vapour Deposition of a Copper Gallium Oxide Spinel. ChemPlusChem 2014, 79 (1), 122-127.

(13) O’Donoghue, R.; Rahman, S.; Mallick, B.; Winter, M.; Rogalla, D.; Becker, H.-W.; Devi, A. Molecular Engineering of Ga-Ketoiminates: Synthesis, Structure and Evaluation as Precursors for the Additive-Free Spin-Coated Deposition of Gallium Oxide Thin Films. New J. Chem. 2018, 42 (5), 3196-3210.

(14) Feng, Q.; Li, F.; Dai, B.; Jia, Z.; Xie, W.; Xu, T.; Lu, X.; Tao, X.; Zhang, J.; Hao, Y. The Properties of Gallium Oxide Thin Film Grown by Pulsed Laser Deposition. Appl. Surf. Sci. 2015, 359, 847-852.

(15) Marchand, P.; Carmalt, C. J. Molecular Precursor Approach to Metal Oxide and Pnictide Thin Films. Coord. Chem. Rev. 2013, 257 (23-24), 3202-3221.

(16) Ortiz, A.; Alonso, J. C.; Andrade, E.; Urbiola, C. Structural and Optical Characteristics of Gallium Oxide Thin Films Deposited by Ultrasonic Spray Pyrolysis. J. Electrochem. Soc. 2001, 148 (2), F26-F29.

(17) Winkler, N.; Wibowo, R. A.; Kautek, W.; Ligorio, G.; ListKratochvil, E. J. W.; Dimopoulos, T. Nanocrystalline $\mathrm{Ga}_{2} \mathrm{O}_{3}$ Films Deposited by Spray Pyrolysis from Water-Based Solutions on Glass and TCO Substrates. J. Mater. Chem. C 2019, 7 (1), 69-77.

(18) Bhattacharya, S.; Singh, S.; Gupta, V. D. A Structural Study on Gallium and Indium $\beta$-Diketonates. J. Chem. Crystallogr. 2002, 32 (9), 299-305.

(19) Pugh, D.; Marchand, P.; Parkin, I. P.; Carmalt, C. J. Group $13 \beta$ Ketoiminate Compounds: Gallium Hydride Derivatives As Molecular Precursors to Thin Films of $\mathrm{Ga}_{2} \mathrm{O}_{3}$. Inorg. Chem. 2012, 51 (11), 63856395.

(20) Bourget-Merle, L.; Lappert, M. F.; Severn, J. R. The Chemistry of $\beta$-Diketiminatometal Complexes. Chem. Rev. 2002, 102 (9), 30313066

(21) Knapp, C. E.; Dyer, C.; Chadwick, N. P.; Hazael, R.; Carmalt, C. J. Metal $\beta$-Diketoiminate Precursor Use in Aerosol Assisted Chemical Vapour Deposition of Gallium- and Aluminium-Doped Zinc Oxide. Polyhedron 2018, 140, 35-41.

(22) Novikov, R. A.; Potapov, K. V.; Chistikov, D. N.; Tarasova, A. V.; Grigoriev, M. S.; Timofeev, V. P.; Tomilov, Y. V. Synthesis and Structures of Cyclopropanedicarboxylate Gallium Complexes. Organometallics 2015, 34 (17), 4238-4250.

(23) Jana, B.; Honaker, C.; Uhl, W. Di(Tert-Butyl)Aluminum, -Gallium and -Indium $\beta$-Diketonates and $\beta$-Diketiminates, Reactions with Oxygen and Formation of an Unprecedented Peroxo-Rich Hexaperoxotriindium Compound. J. Organomet. Chem. 2018, 856, $78-86$.

(24) Valet, M.; Hoffman, D. M. Synthesis of Homoleptic Gallium Alkoxide Complexes and the Chemical Vapor Deposition of Gallium Oxide Films. Chem. Mater. 2001, 13 (6), 2135-2143.

(25) Knapp, C. E.; Pugh, D.; McMillan, P. F.; Parkin, I. P.; Carmalt, C. J. Synthetic and Structural Studies of Donor-Functionalized Alkoxy Derivatives of Gallium. Inorg. Chem. 2011, 50 (19), 9491-9498.

(26) Knapp, C. E.; Marchand, P.; Dyer, C.; Parkin, I. P.; Carmalt, C. J. Synthesis and Characterisation of Novel Aluminium and Gallium Precursors for Chemical Vapour Deposition. New J. Chem. 2015, 39 (8), 6585-6592.

(27) Basharat, S.; Knapp, C. E.; Carmalt, C. J.; Barnett, S. A.; Tocher, D. A. Synthesis and Structures of Gallium Alkoxides. New J. Chem. 2008, 32 (9), 1513-1518.

(28) Knapp, C. E.; Wann, D. A.; Bil, A.; Schirlin, J. T.; Robertson, H. E.; McMillan, P. F.; Rankin, D. W. H.; Carmalt, C. J. Dimethylalkoxygallanes: Monomeric versus Dimeric Gas-Phase Structures. Inorg. Chem. 2012, 51 (5), 3324-3331.

(29) Jung, E. A.; George, S. M.; Han, J. H.; Park, B. K.; Son, S. U.; Kim, C. G.; Chung, T. M. Indium Complexes Bearing Donor-Functionalized Alkoxide Ligands as Precursors for Indium Oxide Thin Films. J. Organomet. Chem. 2017, 833, 43-49.
(30) Biegger, F.; Rameshan, C.; Opitz, A. K.; Noll, J.; Haunold, T.; Lang, H.; Barth, S. Thioether Functionalised Gallium and Indium Alkoxides in Materials Synthesis. New J. Chem. 2016, 40, 6962.

(31) Nakata, N.; Kato, S.; Niyomura, O.; Ebihara, M. Group 13 Metal Carbochalcogenoato Complexes: Synthesis, X-Ray Structure Analysis, and Reactions. Heteroat. Chem. 2018, 29 (5-6), e21445.

(32) Margulieux, K. R.; Sun, C.; Kihara, M. T.; Colson, A. C.; Zakharov, L. N.; Whitmire, K. H.; Holland, A. W.; Pak, J. J. Synthesis and Characterization of Bimetallic Single-Source Precursors $\left(\mathrm{Ph}_{3} \mathrm{P}\right)_{2} \mathrm{M}$ $(\mu \text {-SEt })_{2} \mathrm{E}(\mathrm{SEt})_{2}$ for $\mathrm{MES}_{2}$ Chalcopyrite Materials $(\mathrm{M}=\mathrm{Cu}, \mathrm{Ag}$ and $\mathrm{E}=$ In, Ga, Al). Eur. J. Inorg. Chem. 2017, 2017 (13), 2068-2077.

(33) Novikov, R. A.; Denisov, D. A.; Potapov, K. V.; Tkachev, Y. V.; Shulishov, E. V.; Tomilov, Y. V. Ionic Ga-Complexes of Alkylidene- and Arylmethylidenemalonates and Their Reactions with Acetylenes: An In-Depth Look into the Mechanism of the Occurring Gallium Chemistry. J. Am. Chem. Soc. 2018, 140, 14381-14390.

(34) Dolomanov, O. V.; Bourhis, L. J.; Gildea, R. J.; Howard, J. A. K.; Puschmann, H. OLEX2: A Complete Structure Solution, Refinement and Analysis Program. J. Appl. Crystallogr. 2009, 42 (2), 339-341.

(35) Bourhis, L. J.; Dolomanov, O. V.; Gildea, R. J.; Howard, J. A. K.; Puschmann, H. The Anatomy of a Comprehensive Constrained, Restrained Refinement Program for the Modern Computing Environment - Olex2 Dissected. Acta Crystallogr., Sect. A: Found. Adv. 2015, 71 (1), 59-75

(36) Sheldrick, G. M. IUCr. SHELXT - Integrated Space-Group and Crystal-Structure Determination. Acta Crystallogr., Sect. A: Found. Adv. 2015, 71 (1), 3-8.

(37) Suslova, E. V.; Kessler, V. G.; Gohil, S.; Turova, N. Y. Oxoethoxide Chlorides - Representatives of Oligonuclear Alkoxide Complexes of Gallium: Penta- and Dodecanuclear Molecules. Eur. J. Inorg. Chem. 2007, 2007 (33), 5182-5188.

(38) Suslova, E. V.; Turova, N. Y.; Mityaev, A. S.; Kepman, A. V.; Gohil, S. Gallium Alkoxides: Synthesis and Properties. Russ. J. Inorg. Chem. 2008, 53 (5), 665

(39) Imbrogno, J.; Ferrier, R. C.; Wheatle, B. K.; Rose, M. J.; Lynd, N. A. Decoupling Catalysis and Chain-Growth Functions of Mono $(\mu$ Alkoxo)Bis(Alkylaluminums) in Epoxide Polymerization: Emergence of the N-Al Adduct Catalyst. ACS Catal. 2018, 8 (9), 8796-8803.

(40) Mishra, S.; Jeanneau, E.; Daniele, S.; Mendez, V. AminoalkoxoSupported Heteroleptic Hexanuclear Gallium(III) Wheel as a Synthon for Group 13 Heterometallics: A Rare Sol-Gel Precursor for Mixed AlGa Oxide as Support for Gold Catalysts $\dagger$. Dalt. Trans. 2010, 39, 74407443

(41) Knapp, C. E.; Pemberton, L.; Carmalt, C. J.; Pugh, D.; McMillan, P. F.; Barnett, S. A.; Tocher, D. A. Synthesis, AACVD and X-Ray Crystallographic Structures of Group 13 Monoalkoxometallanes. Main Group Chem. 2010, 9 (1-2), 31-40.

(42) Addison, A. W.; Rao, T. N.; Reedijk, J.; van Rijn, J.; Verschoor, G. C. Synthesis, Structure, and Spectroscopic Properties of Copper (II) Compounds Containing Nitrogen-Sulphur Donor Ligands; the Crystal and Molecular Structure of Aqua. J. Chem. Soc. Dalt. Trans. 1984, No. 7, $1349-1356$.

(43) Cambridge, J. K. M. R. K.; Harris. Nuclear Magnetic Resonance Spectroscopy. Magn. Reson. Chem. 1987, 25 (3), 280-280.

(44) Londaitsbehere, A.; Herrera, M.; Salgado, A.; Mosquera, M. E. G.; Cuenca, T.; Cano, J. Nondissociative Mechanism for the Inversion of the Configuration in Cyclopentadienyl Di(Aryloxo)Titanium Complexes: An Entropy Discussion. Organometallics 2017, 36 (20), 3904-3911.

(45) Asatryan, R.; Ruckenstein, E.; Hachmann, J. Revisiting the Polytopal Rearrangements in Penta-Coordinate D7-Metallocomplexes: Modified Berry Pseudorotation, Octahedral Switch, and Butterfly Isomerization. Chem. Sci. 2017, 8 (8), 5512-5525.

(46) Couzijn, E. P. A.; Slootweg, J. C.; Ehlers, A. W.; Lammertsma, K. Stereomutation of Pentavalent Compounds: Validating the Berry Pseudorotation, Redressing Ugi's Turnstile Rotation, and Revealing the Two- and Three-Arm Turnstiles. J. Am. Chem. Soc. 2010, 132 (51), 18127-18140. 
(47) Li, N.; Qiu, R.; Zhang, X.; Chen, Y.; Yin, S. F.; Xu, X. Strong Lewis Acids of Air-Stable Binuclear Triphenylantimony(V) Complexes and Their Catalytic Application in C-C Bond-Forming Reactions. Tetrahedron 2015, 71 (25), 4275-4281.

(48) Frisch, M. J.; Trucks, G. W.; Schlegel, H. B.; Scuseria, G. E.; Robb, M. A.; Cheeseman, J. R.; Scalmani, G.; Barone, V.; Mennucci, B.; Petersson, G. A.; Nakatsuji, H.; Caricato, M.; Li, X.; Hratchian, H. P.; Izmaylov, A. F.; Bloino, J.; Zheng, G.; Sonnenberg, J. L.; Hada, M.; Ehara, M.; Toyota, K.; Fukuda, R.; Hasegawa, J.; Ishida, M.; Nakajima, T.; Honda, Y. K. O.; Nakai, H.; Vreven, T.; Montgomery, J. A., Jr.; Peralta, J. E.; Ogliaro, F.; Bearpark, M.; Heyd, J. J.; Brothers, E.; Kudin, K. N.; Staroverov, V. N.; Kobayashi, R.; Normand, J.; Raghavachari, K.; Rendell, A.; Burant, J. C.; Iyengar, S. S.; Tomasi, J.; Cossi, M.; Rega, N.; Millam, J. M.; Klene, M.; Knox, J. E.; Cross, J. B.; Bakken, V.; Adamo, C.; Jaramillo, J.; Gomperts, R.; Stratmann, R. E.; Yazyev, O.; Austin, A. J.; Cammi, R.; Pomelli, C.; Ochterski, J. W.; Martin, R. L.; Morokuma, K.; Zakrzewski, V. G.; Voth, G. A.; Salvador, P.; Dannenberg, J. J.; Dapprich, S.; Daniels, A. D.; Farkas, Ö.; Foresman, J. B.; Ortiz, J. V.; Cioslowski, J.; Fox, D. J. Gaussian 09, Rev. D.01; Gaussian, Inc.: Wallingford, CT, 2009.

(49) Nguyen, A. H. T.; Tennant, J. L.; Maxton, L. J.; Holland, A. W. Solution State Fluxionality and Thermolysis Reactions of Bimetallic Single Source Precursors for I-III-VI Chalcopyrite Materials. Inorg. Chim. Acta 2018, 480, 189-196. 